\title{
Assessment of food security in Kazakhstan in conditions of crisis Covid 19
}

\author{
Zh. Zh. Yeszhanova, D.D. Yermekbayeva, U.A. Myrzayeva \\ University of International Business
}

\begin{abstract}
In the article, the authors analyzed the changes in the main components of food security in Kazakhstan for 2020 to clarify the question of how the crisis associated with the Covid 19 coronavirus pandemic affected its level. The authors analyzed the main components of food security: they assessed the dynamics of changes in the physical and economic accessibility of food in the country, the quality and safety of products, sustainability and availability of resources, and also compared them with the average value of these criteria for 113 countries. A comparative analysis showed that the level of food security in our country exceeds the average level for the compared countries, and during the quarantine period Kazakhstan managed to increase these indicators, which indicates the effectiveness of the government measures taken to support the development of agricultural producers to ensure uninterrupted food delivery.

Key words: food security, food, economic accessibility, physical accessibility, Covid 19 pandemic, Kazakhstan.
\end{abstract}

\section{Covid 19 дағдарысы жағдайындағы Қазақстандағы азық-түлік қауіпсіздігін бағалау}

Түйін

Мақалада авторлар Covid 19 коронавирус пандемиясымен байланысты дағдарыстың оның деңгейіне қалай әсер еткенін анықтау мақсатында Қазақстанның 2020 жылғы азық-түлік қауіпсіздігінің негізгі құрамдастарының өзгеруіне талдау жасады. Авторлар азық-түлік қауіпсіздігінің негізгі компоненттеріне талдау жасады: елдегі азық-түліктің физикалық және экономикалық қол жетімділігінің өзгеру динамикасы, өнімнің сапасы мен қауіпсіздігі, ресурстардың тұрақтылығы мен қол жетімділігі, сонымен қатар 113 ел үшін осы критерийлердің орташа мәнімен салыстырылды. Жүргізілген салыстырмалы талдау біздің еліміздегі азық-түлік қауіпсіздігі деңгейі салыстырылатын елдер бойынша орташа деңгейден асып түсетінін көрсетті және карантиндік кезеңде Қазақстан осы көрсеткіштерді арттыра алды, бұл азық-түлік өнімдерін үздіксіз жеткізуді қамтамасыз ету үшін ауыл шаруашылығы өндірушілерін дамытуды қолдау бойынша қабылданған мемлекеттік шаралардың тиімділігін көрсетеді.

Түйін сөздер: азық-түлік қауіпсіздігі, азық-түлік, экономикалық қолжетімділік, физикалық қолжетімділік, Covid 19 пандемиясы, Қазақстан.

\section{Оценка продовольственной безопасности Казахстана в условиях кризиса Covid 19}

\section{Аннотация}

В статье авторы провели анализ изменения основных составляющих продовольственной безопасности Казахстана за 2020 год с целью выяснения вопроса, как кризис, связанный с пандемией коронавируса Covid 19, повлиял на ее уровень. Авторами проведен анализ основных составляющих продовольственной безопасности: оценена динамика изменения физической и экономической доступности продовольствия в стране, качества и безопасности продукции, устойчивости и наличия ресурсов, а также проведено сравнение со средним значением данных критериев по 113 странам. Проведенный сравнительный анализ показал, что уровень продовольственной безопасности в нашей стране превышает средний уровень по сравниваемым странам, и за карантинный период Казахстану удалось увеличить данные показатели, что свидетельствует об эффективности принятых государственных мер по поддержке развития сельхозпроизводителей для обеспечения бесперебойной доставки продуктов питания.

Ключевые слова: продовольственная безопасность, продовольствие, экономическая доступность, физическая доступность, пандемия Covid 19, Казахстан.

\section{Introduction}

The coronavirus pandemic in 2020 has dramatically changed the economic situation around the world, and this impact has especially affected the level of food security. The problem of malnutrition has escalated sharply in several countries amid the global economic downturn. In East and Central Asia alone, the number of hungry people could rise by $135 \%$.
The cumulative impact of Covid-19, its suppression measures and the ensuing global economic downturn will exacerbate hunger and malnutrition and increase the number of people living in poverty and hunger, especially in lowincome countries that depend on food imports. It can be assumed that this situation will undo the progress made in the course of ten years in poverty reduction. Moreover, the pandemic came at the time when food security and our food systems 
were already under strain. Conflict, natural disaster, climate change, and the arrival of pests and plagues on a transcontinental scale preceded COVID-19 and were already undermining food security in many contexts.

FAO is assessing the Covid-19 threat to food security and nutrition and developing evidencebased policies for members. Unlike the food crisis of 2007-2008, the problem today is not food availability, but access to it. The food supply chains remain intact, but the economic situation in the countries begins to deteriorate; the current situation poses a serious threat, as the economic downturn is superimposed on the problem of hunger. FAO estimates that up to 80.3 million people are threatened by hunger associated with reduced economic growth.

\section{Literature review}

An active search for various ways to improve the efficiency of the agro-industrial complex and ensure food security began at the beginning of the twentieth century. Various aspects of the problem of ensuring food security are reflected in the studies of leading Western scientists, in the works of B. Stokes, D. Byrley, E. Barber, G. Conway, B. Portila, J. Burinet, M. Floi [1,2,3].

The issues of ensuring the sustainability of the development of the agri-food sector are reflected in the works of Russian researchers: A. Alexandrov, R.R. Gumerov, A. Emelyanov, E.V. Zarova, A. Ilyicheva, A. V. Korbut, N.E. Kudratov, R. Kuchukov, S. Mikhnevich, S.U. Nuraliev, N.S. Ogluzdin, A. Orlov, E.V. Serova, Yu.S. Khromov. I.M Kulikov., I.A. Minakov and others $[4,5,6,7,8,9]$.

In recent years, problems of the country's food security have been actively discussed in Kazakhstan. The research of organizational and economic issues in the agri-food sphere is the subject of the works of scientists K.A. Sagadiev, R.A. Alshanov, A. Ashimbaeva, K.T. Arystanbekov, M. Esenbaev, Sh. Imangazhin, S. A. Abdildin, H. Ertazin $[9,10,11]$.

Theoretical and methodological issues of food security are reflected in the works of scientists A.A. Satybaldin, L.A. Bimendieva, G.N. Gamarnik, M.U. Spanov, N.K. Mamyrov, K.S. Mukhtarova, A.R. Kenzhebaeva, A.S. Tembetov, Kaygorodcev A.A. $[12,13,14,15]$.

At the same time, it should be noted that the methodological aspects of assessing food security in the context of the crisis phenomena caused are insufficiently studied and require additional research.

Research question: how the crisis caused by the Covid 19 pandemic affected the food security of Kazakhstan.

\section{Research methodology}

The study implements an integrated approach to assessing food security, based on general scientific research methods, which include methods of comparative analysis, generalization, systematization, empirical research method, statistical methods.

The study of the level of food security was carried out by analyzing the main indicators of food security in the Republic of Kazakhstan. To determine the impact of the Covid 19 pandemic crisis, the series of dynamics of the main indicators of the country's food security in recent years were analyzed. To identify the strengths and weaknesses of the country in terms of food security, a comparative analysis was carried out with the corresponding indicators of 113 countries of the world.

To develop proposals to improve food security in Kazakhstan, an analysis of the instruments of state support for the development of the agri-food sector, the policy of ensuring the physical and economic accessibility of food to the population of the country was carried out.

The regulatory legal acts of the Republic of Kazakhstan in the field of ensuring food security, official data of the Committee on Statistics of the Ministry of National Economy of the Republic of Kazakhstan, as well as data from the analytical division of the British magazine The Economist Intelligence Unit were used as an information base.

To answer the posed research question, the authors used the methodology for assessing the level of food security, adopted by the analytical division of the British magazine The Economist Intelligence Unit. There are many different methods for assessing the food security of countries, the choice of this method is explained by the fact that according to the chosen approach, a comprehensive assessment of food security is based on a wide range of socio-economic indicators, which, according to the authors, allows obtaining more accurate results that consider different aspects of social -economic development of the country.

\section{Results and discussion}

Food security is one of the priorities in the economic policy of Kazakhstan. To achieve it, a program for the development of the agro-industrial complex is being implemented, which will end in 2021. It will be replaced by a similar five-year national project.

"Our main tasks are self-sufficiency in socially significant food products, a stable increase in the incomes of millions of rural residents, an increase in labor productivity by two and a half times, an increase in the export of agricultural products by two times," said the President of the Republic 
of Kazakhstan Kassym-Zhomart Tokayev in his message to the people on September 1, of the year 2020 [16].

According to the 2020 Global Food Security Index which was compiled by The Economist on behalf of Corteva, global food security is continuing to deteriorate across the world due to a combination of factors, primarily intensive farming and climate change. While there were strains on global food systems prior to the pandemic, Covid-19 has exacerbated existing problems, making life even more difficult for farmers. The Global Food Security Index is based on 59 unique indicators and it measures the state of food affordability, availability, quality, safety and natural resources/ resilience in 113 countries. Finland was named the top country for food security in 2020, ahead of Ireland and the Netherlands. Despite problems caused by Brexit, the United Kingdom was ranked 6th while the United States and Canada came 11th and 12 th, respectively [17].

According to the analytical division of the British magazine The Economist - Intelligence Unit, in 2020 Kazakhstan ranked 32nd out of 113 countries in terms of food security, being between Australia and Kuwait (Table 1). In 2019, the republic was on the 48th line, in 2018 - on the 57 th. If we compare with the post-Soviet countries, then in 2020 the ratings of countries in terms of food security were as follows: Belarus took 23rd place, Russia - 24th, Ukraine - 54th, Azerbaijan - 56th, Uzbekistan - 83rd, Tajikistan - 85th.

Table 1 - Rating of countries in terms of food security

\begin{tabular}{|c|c|c|c|c|c|c|c|c|c|c|c|c|}
\hline Rank & $\Delta$ & Country & 2012 & 2013 & 2014 & 2015 & 2016 & 2017 & 2018 & 2019 & 2020 & $\Delta$ \\
\hline 23 & $\Delta 2$ & Belarus & 65,4 & 68,2 & 65,8 & 68,5 & 68,3 & 71,3 & 72,0 & 73,3 & 73,8 & $+0,5$ \\
\hline 24 & $\Delta 6$ & Russia & 66,6 & 65,9 & 63,0 & 62,6 & 67,8 & 70,3 & 70,3 & 72,1 & 73,7 & $+1,6$ \\
\hline 25 & $\nabla 2$ & Poland & 71,3 & 74,0 & 75,5 & 74,4 & 73,9 & 73,4 & 75,9 & 74,2 & 73,5 & $-0,7$ \\
\hline 26 & $\nabla 2$ & Spain & 73,1 & 74,8 & 74,9 & 73,9 & 75,0 & 73,4 & 74,4 & 73,6 & 73,4 & $-0,2$ \\
\hline 27 & $\nabla 5$ & Greece & 71,5 & 71,7 & 74,3 & 74,8 & 75,2 & 75,1 & 74,9 & 74,8 & 73,0 & $-1,8$ \\
\hline 28 & $\Delta 1$ & CostaRica & 71,7 & 72,6 & 70,4 & 72,0 & 71,8 & 70,3 & 71,9 & 72,3 & 72,3 & 0 \\
\hline 29 & $\nabla 1$ & SouthKorea & 71,2 & 71,8 & 71,5 & 71,5 & 71,6 & 73,2 & 72,5 & 72,8 & 72,1 & $-0,7$ \\
\hline 30 & $\Delta 3$ & Uruguay & 63,8 & 65,8 & 66,2 & 66,2 & 68,3 & 71,2 & 72,4 & 70,5 & 71,4 & $+0,9$ \\
\hline 31 & $\nabla 5$ & Australia & 72,4 & 73,7 & 75,7 & 76,2 & 76,4 & 75,5 & 76,8 & 73,1 & 71,3 & $-1,8$ \\
\hline 32 & $\Delta 10$ & Kazakhstan & 61,1 & 61,5 & 63,4 & 63,3 & 65,0 & 66,2 & 67,0 & 68,1 & 70,8 & $+2,7$ \\
\hline 33 & $\Delta 6$ & Kuwait & 68,4 & 69,5 & 70,2 & 66,6 & 67,0 & 68,6 & 69,0 & 69,2 & 70,7 & $+1,5$ \\
\hline$=34$ & $\nabla 7$ & Chile & 68,5 & 68,8 & 68,4 & 69,0 & 69,1 & 71,2 & 72,8 & 73,0 & 70,2 & $-2,8$ \\
\hline$=34$ & $\Delta 6$ & Oman & 58,4 & 58,7 & 66,4 & 66,8 & 68,2 & 68,9 & 70,3 & 69,1 & 70,2 & $+1,1$ \\
\hline 36 & $\leftrightarrow$ & Hungary & 67,7 & 69,3 & 69,4 & 70,6 & 72,2 & 71,3 & 69,6 & 70,0 & 70,1 & $+0,1$ \\
\hline 37 & $\nabla 6$ & Qatar & 64,9 & 67,4 & 71,1 & 70,0 & 69,8 & 69,9 & 70,3 & 71,7 & 69,6 & $-2,1$ \\
\hline 38 & $\nabla 4$ & SaudiArabia & 64,2 & 66,4 & 68,4 & 69,8 & 68,1 & 69,2 & 67,5 & 70,2 & 69,5 & $-0,7$ \\
\hline 39 & $\nabla 1$ & China & 66,1 & 67,8 & 69,8 & 71,5 & 71,9 & 73,4 & 73,0 & 69,4 & 69,3 & $-0,1$ \\
\hline 40 & $\Delta 1$ & Slovakia & 67,6 & 70,2 & 69,8 & 70,9 & 72,0 & 70,2 & 70,1 & 69,0 & 69,2 & $+0,2$ \\
\hline 41 & $\nabla 4$ & Panama & 62,7 & 64,0 & 66,4 & 66,9 & 66,5 & 69,4 & 69,3 & 69,8 & 68,9 & $-0,9$ \\
\hline 42 & $\nabla 8$ & $\begin{array}{l}\text { UnitedArab } \\
\text { Emirates }\end{array}$ & 61,7 & 61,3 & 61,8 & 63,7 & 63,1 & 64,7 & 68,8 & 70,2 & 68,3 & $-1,9$ \\
\hline \multicolumn{13}{|c|}{$\begin{array}{l}\Delta \text { - changes over the last year, } \nabla \text { decline, } \boldsymbol{\Delta} \text { increase, } \leftrightarrow \text { without changes } \\
\text { Note - compiled based on data from source [18] }\end{array}$} \\
\hline
\end{tabular}

The Global Food Security Index (GFSI) considers the issues of food affordability, availability, quality and safety, and natural resources and resilience across a set of 113 countries. The index is a dynamic quantitative and qualitative benchmarking model constructed from 59 unique indicators that measure the drivers of food security across both developing and developed countries.

The 2020 GFSI is the ninth edition of the index. The Economist Intelligence Unit updates the model annually to capture year-on-year changes in structural factors impacting food security [3]. 
According to the adopted methodology, the level of food security is assessed from 0 to 100 points according to the following criteria with appropriate weighting factors:

1) affordability - $32,4 \%$;

2) availability- $32,4 \%$;

3) quality and safety $-17,6 \%$;

4) natural resources \& resilience- $17,6 \%$.

Depending on the overall score, the level of food security is divided into the following levels:

from 0 to 19.9 - very weak;

from 20 to 39.9 - weak; from 40 to 59.9 - medium;

from 60 to 79.9 - good;

80 to 100 is very good.

As can be seen from the data in Table 1, Kazakhstan has a good level of food security throughout the period from 2012 to 2020 . Only Finland (82.4) and Ireland (81.4) were included in the category of countries with the "best" food security in 2020.

It should be noted that at the end of 2020 , Kazakhstan entered the top three countries in terms of the growth rate of the integral indicator of food security (see Table 2).

Table2 - Most improved food security environment score 2020 vs 2019

\begin{tabular}{|c|l|c|c|c|}
\hline 2020 & \multirow{2}{*}{ Country } & 2019 & 2020 & $\Delta$ \\
\cline { 3 - 5 } Rank & & Score & Score & $+4,7$ \\
\hline 105 & Haiti & 33,8 & 38,5 & $+2,7$ \\
\hline 32 & Kazakhstan & 68,1 & 70,8 & $+2,7$ \\
\hline 54 & Ukraine & 60,3 & 63,0 & $+2,6$ \\
\hline 80 & Pakistan & 49,7 & 52,3 & $+2,6$ \\
\hline 22 & Romania & 71,6 & 74,2 & $+2,3$ \\
\hline 61 & Paraguay & 58,2 & 60,5 & $+1,9$ \\
\hline 99 & Mozambique & 38,7 & 40,6 & $+1,8$ \\
\hline 77 & Nepal & 51,2 & 53,0 & \\
\hline \multicolumn{2}{|l|}{ Note - compiled based on data from source [18] } \\
\hline
\end{tabular}

Now we move on to a more detailed analysis of the components of Kazakhstan's food security during the pandemic.

Economic affordability of food increased by 1.2 points and by this criterion the country took 43rd place among 113 countries, having risen by 6 positions. This criterion is based on the following indicators:
- change in average food costs (medium),

- proportion of population under global poverty line (very good),

- inequality-adjusted income index (good),

- agricultural import tariffs (good),

- food safety net programs (very good),

- market access and agricultural financial services (very good).

Table 3 - Food security indicators of the Republic of Kazakhstan in 2020

\begin{tabular}{|l|c|c|c|c|c|}
\hline \multicolumn{1}{|c|}{ Series } & Levels & Score & $\Delta$ & \multicolumn{1}{c|}{ Rank } & \multicolumn{1}{c|}{$\Delta$} \\
\hline \multicolumn{1}{|c|}{1} & 2 & 3 & 4 & \multicolumn{1}{c|}{5} & \multicolumn{1}{c|}{6} \\
\hline Overall food security environment & good & $\mathbf{7 0 , 8}$ & $+\mathbf{2 , 7}$ & $\mathbf{3 2}$ & $\mathbf{\Delta 1 0}$ \\
\hline 1) Affordability & good & 79,0 & $+1,2$ & 43 & $\mathbf{\Delta 6}$ \\
\hline 2) Availability & good & 65,7 & $+5,9$ & 31 & $\mathbf{\Delta 2 3}$ \\
\hline 3) Quality and safety & very good & 83,7 & $+3,3$ & $=31$ & $\mathbf{\Delta 6}$ \\
\hline 4) Natural resources \& resilience & moderate & 52,4 & $-\mathbf{0 , 8}$ & 35 & $\mathbf{\nabla 4}$ \\
\hline 1) Affordability & good & $\mathbf{7 9 , 0}$ & $+\mathbf{1 , 2}$ & $\mathbf{4 3}$ & $\mathbf{\Delta 6}$ \\
\hline 1.1) Change in average food costs & weak & 35,0 & $+5,5$ & +99 & $\leftrightarrow$ \\
\hline 1.2) Proportion of population under global poverty line & very good & 99,6 & 0 & $=24$ & $\mathbf{\Delta 1}$ \\
\hline
\end{tabular}


Zh. Zh. Yeszhanova, D.D. Yermekbayeva, U.A. Myrzayeva / Экономика: стратегия и практика, № 2 (16), 2021 2./145-153

\begin{tabular}{|c|c|c|c|c|c|}
\hline 1 & 2 & 3 & 4 & 5 & 6 \\
\hline 1.3) Inequality-adjusted income index & good & 73,2 & $+0,1$ & +20 & $\nabla 1$ \\
\hline 1.4) Agricultural import tariffs & good & 77,9 & $+1,7$ & +16 & $\Delta \mathbf{1}$ \\
\hline 1.5) Food safety net programs & very good & 100,0 & 0 & $=1$ & $\leftrightarrow$ \\
\hline 1.6) Market access and agricultural financial services & very good & 98,1 & $-1,3$ & 3 & $\Delta 1$ \\
\hline 2) Availability & good & 65,7 & $+5,9$ & 31 & $\Delta 23$ \\
\hline 2.1) Sufficiency of supply & very good & 86,0 & $+1,2$ & $=16$ & $\Delta 4$ \\
\hline 2.2) Agricultural research and development & moderate & 48,0 & $+0,4$ & 27 & $\leftrightarrow$ \\
\hline 2.3) Agricultural infrastructure & moderate & 54,9 & 0 & 47 & $\nabla 1$ \\
\hline 2.4) Volatility of agricultural production & very good & 83,3 & $+33,5$ & $=29$ & $\mathbf{\Delta 5 2}$ \\
\hline 2.5) Political and social barriers to access & good & 62,3 & 0 & $=47$ & $\Delta 1$ \\
\hline 2.6) Food loss & good & 76,9 & $+3,8$ & +58 & $\Delta \mathbf{1 0}$ \\
\hline 2.7) Food security and access policy commitments & very weak & 0,0 & 0 & $=65$ & $\Delta \mathbf{1}$ \\
\hline 3) Quality and safety & very good & 83,7 & $+3,3$ & $=\mathbf{3 1}$ & $\Delta 6$ \\
\hline 3.1) Dietary diversity & good & 68,7 & 0 & $=27$ & $\leftrightarrow$ \\
\hline 3.2) Nutritional standards & good & 73,5 & 0 & $=32$ & $\Delta 9$ \\
\hline 3.3) Micronutrient availability & very good & 92,0 & 0 & 29 & $\leftrightarrow$ \\
\hline 3.4) Protein quality & very good & 90,0 & 0 & +32 & $\leftrightarrow$ \\
\hline 3.5) Food safety & very good & 88,8 & $+19,3$ & 53 & $\Delta \mathbf{1 6}$ \\
\hline 4) Natural resources \& resilience & moderate & 52,4 & $-0,8$ & 35 & $\nabla 4$ \\
\hline 4.1) Exposure & good & 69,7 & 0 & 41 & $\leftrightarrow$ \\
\hline 4.2) Water & very weak & 10,0 & 0 & $=53$ & $\leftrightarrow$ \\
\hline 4.3$)$ Land & moderate & 53,4 & 0 & 95 & $\leftrightarrow$ \\
\hline 4.4) Oceans, rivers and lakes & very weak & 19,7 & 0 & $=66$ & $\leftrightarrow$ \\
\hline 4.5) Sensitivity & good & 67,6 & $-7,6$ & 67 & $\nabla 19$ \\
\hline 4.6) Political commitment to adaptation & good & 69,2 & 0 & $=10$ & $\leftrightarrow$ \\
\hline 4.7) Demographic stress & good & 67,9 & $+1,1$ & 44 & $\Delta 2$ \\
\hline $\begin{array}{l}\text { Note - compiled based on data from source [18] } \\
\Delta \text { - changes over the last year } \\
\nabla \text { decline, } \\
\Delta \text { increase, } \\
\leftrightarrow \text { without changes }\end{array}$ & & & & & \\
\hline
\end{tabular}

The physical availability of food in the country increased by 5.9 points and according to the value of this indicator Kazakhstan ranked 31st, rising by 23 positions during this period. When assessing the physical accessibility, the following criteria are considered:

- $\quad$ sufficiency of supply (very good),

- agricultural research and development (medium),

- agricultural infrastructure (medium),

- volatility of agricultural production (very good),

- political and social barriers to access (good),

- food losses (good),

- food security and food access policy commitments (very weak).
Food quality and safety, the value of this criterion increased over the year by 3.3 points and allowed the country to rank 31 st. It is based on the following indicators:

- dietary diversity (good),

- nutritional standards (good),

- micronutrient availability (very good),

- protein quality (very good),

- food safety (very good).

Natural resources and resilience

- exposure (good),

- water (very weak),

- land (medium),

- oceans, rivers and lakes (very weak),

- sensitivity (good),

- political adaptation orientation (good),

- demographic stress (good). 
Analyzing the dynamics of the general indicator of food security, it is worth noting the trend of steady growth since 2012, as well as the constant excess of the average for 113 countries during the period under review (Figure 1).

In terms of the dynamics of the indicator of the economic affordability of food, temporary insignificant recessions and rises are observed, while it is worth noting that in 2020 this indicator has significantly increased compared to the previous one, which indicates that the pandemic crisis has not so strongly affected the economic affordability of food in Kazakhstan. At the same time, there is a significant excess of the average level for all countries throughout the study period.

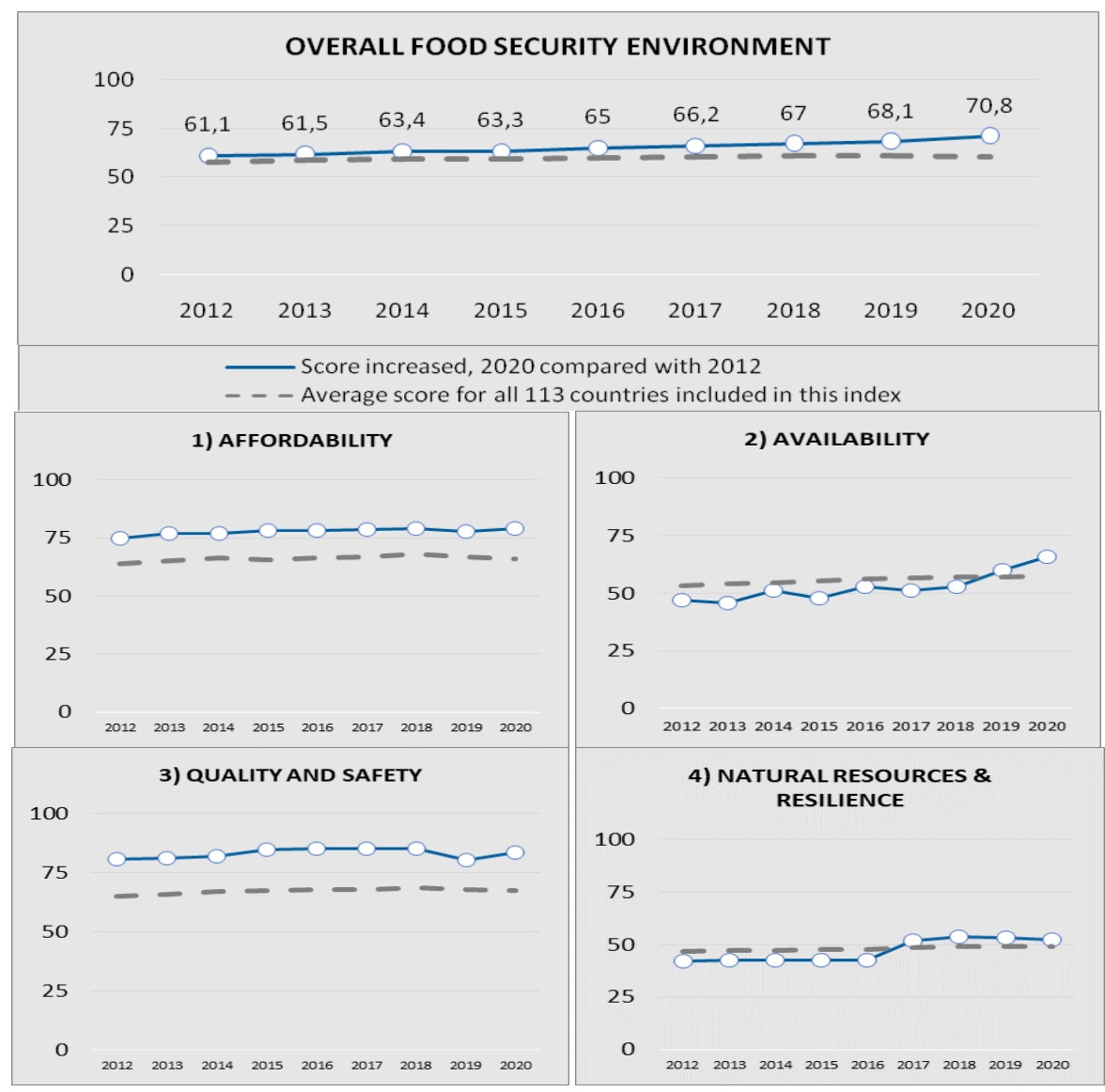

Note - compiled based on data from source [18]

Figure 1 - Dynamics of changes in food security indicators of the Republic of Kazakhstan and the average for 113 countries

Observation of the trend of changes in the physical availability of food in Kazakhstan indicates an increase in this indicator, the decline took place in 2013, 2015 and 2017. At the same time, in 2020 , the physical availability of food increased significantly from 59.8 to 65.7 . It is worth noting that food was available in Kazakhstan at a level below the national average until 2019, after which the level rose above the average. Here, the negative impact of the pandemic on food security in other countries may have played a role and lowered the average.

The dynamics of indicators of the quality and safety of food products is positive, in 2019 there was a significant decline, over the past year it is increasing again, but the level of 2018 has not yet been reached. According to this criterion, the indicators of Kazakhstan significantly exceed the average level for all 113 countries, which indicates a high quality and safety of food products in Kazakhstan. 
Natural resources and sustainability are the only indicators of the food security environment that declined in Kazakhstan in 2020. At the same time, its level until 2017 was less than the average, in 2020 it was almost equal to the average. Here, the weakest criteria are water, rivers, lakes and oceans. Kazakhstan, being the largest landlocked country, is also located at the farthest distance from the world's oceans.

Kazakhstan is an agro-industrial country, the agro-industrial sector of which not only meets the needs of the domestic market, but also allows some of its products to be exported. The agro-industrial complex includes the production of agricultural products, their processing and the supply system to consumers, including industry, for example, textiles.

There have been no large-scale interruptions in the supply of food in Kazakhstan since the beginning of the quarantine. And some delays were associated only with the situation at the state borders, where control was strengthened due to the epidemiological situation.

There was no food shortage even in March and April - that is, at the very beginning of the quarantine, when both citizens and businesses had to quickly adapt to new restrictions on work and movement.

"The government controls the issue of food supply throughout the country. We certainly have enough products, now we need to ensure affordability of prices and proper logistics in order not to create a stir," said Kassym-Zhomart Tokayev at a meeting of the State Commission on the State of Emergency on April 10.

Despite the conditions of the pandemic, there is a positive trend in the agricultural sector. According to statistical data, the gross output of products (services) in agriculture, forestry and fisheries in January-July 2020 in the country as a whole amounted to 1,679.1 billion tenge, which is $2.5 \%$ higher than the level of the corresponding period of the previous year.

The growth in the production of agricultural, forestry and fishery products in January-July 2020 is due to an increase in crop production by $2.1 \%$, slaughter of livestock and poultry in live weight by $3.6 \%$, and raw cow milk yields by $3 \%$ [19].

In 2020, there was a good grain harvest. If in 2019 they harvested about 17.4 million tons of grain in total, then by the beginning of October 2020 more than 20 million tons. This means stability in the production of bakery products in the country: in 2019 , for example, the rise in the price of flour due to a poor harvest was called one of the reasons for the rise in prices for these products.

Food security in the country is ensured by the constant development of companies working in agriculture and agricultural processing. So, according to the Ministry of Agriculture of the country, in 2019, investments in fixed assets in agriculture increased by more than $41 \%$, reaching 501.6 billion tenge.

The state plays a significant role in supporting the sector's enterprises. For example, within the framework of the State Program for the Development of the Agro-Industrial Complex for 2017-2021 alone, it is planned to allocate about 2.77 trillion tenge from the republican and local budgets.

At the same time, the largest creditor of the industry is the national holding KazAgro, whose subsidiaries - the Agrarian Credit Corporation, the Fund for Financial Support of Agriculture and Kazagrofinance - financially support the agricultural industry. In 2019, the holding financed the agribusiness entities for 477 billion tenge. If we take a long-term cut, then the Agrarian Credit Corporation alone from 2001 to 2019 provided loans to the agricultural industry of Kazakhstan for 1.28 trillion tenge.

As a state with a raw material orientation, the economy of the Republic of Kazakhstan is trying to limit the export of raw materials and stimulate deep processing of raw materials.

Restrictions on the export of raw materials are the methods of quotas and licensing, the introduction of a ban on export, and increased customs duties.

So, now there is a ban on the export of buckwheat, white sugar, potatoes, onions, garlic, seeds and sunflower oil. Quotas have been introduced for carrots, turnips, beets, cabbage, as well as flour and wheat.

Methods to stimulate exports are to reduce taxes and customs duties on exported products of deep processing. In addition, the state provides consulting support to exporters, compensates for the costs of participation in exhibitions [20].

Against the backdrop of the pandemic, the state continues to help agriculture. First - to provide citizens with food. "The current situation has clearly confirmed the well-known truth: food security is a key element of the security of the state. Therefore, we will continue to provide maximum support to the agrarians," Kassym-Zhomart Tokayev said in May, at the final meeting of the State Commission on the State of Emergency.

The government and the Atameken National Chamber of Entrepreneurs are to launch a pilot project in several regions to develop a cooperative chain in the countryside "from field to counter". This will be done to support more than 1.7 million personal subsidiary farms, whose products are not officially sold through retail chains and are not supplied to processing plants. 
In addition, the head of state announced the need to establish a system for the constant purchase and sale of agricultural products, as well as launch training and increase the agricultural competence of participants. All this, according to the country's leadership, will increase the incomes of about 2 million rural residents, increase the load on domestic agricultural enterprises up to $70 \%$ and, importantly, reduce the import of socially significant products.

Conclusion. Thus, summarizing the study, it is important to note the effectiveness of the government measures taken to support agricultural producers, which made it possible not only to maintain at the same level, but even to increase the food security indicators of our country during the difficult period of the crisis.

However, there are still many unresolved problems. The analysis of the components of food security has shown the existing weaknesses.

If deficiencies such as oceans, rivers and lakes cannot be addressed, and access to water is difficult for Kazakhstan, then issues such as political commitment to food security and access, changes in average food costs are solvable and these positions need to be strengthened.

Comparative analysis showed that the indicators of agricultural research and development, agricultural infrastructure in Kazakhstan is at an average level. However, these important positions require special attention from public policy, since the level of their development directly determines the food security of the country.

The level of labor productivity in the agricultural sector remains at a low level compared to other sectors of the economy. The main reasons for such a low indicator can be attributed to the issues of insufficient technical equipment, implementation, transfer of effective agricultural technologies and their availability for small and medium-sized farms.

Another important issue affecting both labor productivity in agriculture and ensuring the food security of the country is the weak interaction between agro-science and the business community. At the same time, domestic agrarians are in dire need of the introduction of effective technologies. It is necessary to select the optimal format for interaction between the two parties the scientific community and business, including small ones. Until this aspect is resolved, then you should not expect any big effects. Here it is worth highlighting the problem of staffing. According to the data of local executive bodies, about $80 \%$ of the subjects of the agro-industrial complex are in dire need of specialists. It should be noted that enough educational grants are allocated annually for training in agricultural specialties. However, at the exit, only half of the graduates of agricultural universities are employed in rural areas. Some of them work only formally, but in fact are employed in other areas.

Important are the problems of storage and marketing of agricultural products, which directly affect the level of competitiveness of the agricultural sector. The underdevelopment of the trade and logistics system, the practical absence of facilities for the pre-sale preparation of goods (washing, packing, drying, calibration and transportation, etc.) does not ensure a uniform supply of quality raw materials throughout the year. So, in some regions, the warehouse infrastructure for the storage of fruits and vegetables and food products is underdeveloped.

Thus, there are many unresolved problems in the agricultural sector of Kazakhstan, and the fact that it raised the rating in terms of food security over the past period does not give reasons to relax, further measures are needed to strengthen the country's weak positions.

\section{References}

1. Stouks B. (2001). Globalizacija v zerkale obshhestvennogo mnenija. Mezhdunarodnaja politika(№7), 15. (in Russ.)

2. Maslakov V.V. (1996). Formirovanie i razvitie sistemy prodovol'stvennoj bezopansosti: konceptual'nye podhody. Ekaterinburg.

3. Kudratov N.Je., Askarov N. A., Isahov B.A. (2001). Metodicheskie voprosy ocenki urovnja razvitija jeksportnogo potenciala regionov. Voprosy statistiki, 2.

4. Korolev I., Zhukovskaja V., Chertko N. (2011). Import i prodovol'stvennaja bezopasnost' Rossii. Mirovaja jekonomika i mezhdunarodnye otnoshenija, $11,13-20$

5. Kulikov I.M., Minakov I.A. (2016). Prodovol'stvennaya bezopasnost' $\mathrm{v}$ sfere proizvodstva i potrebleniya plodoovoshchnoj produkcii [Food security in the production and consumption of fruits and vegetables]. Agribusiness: Economy, Management, 2, 4-16.

6. Serova E. (2001). Prodovol'stvennaja bezopasnost' strany: agrarno-jekonomicheskij aspekt. Moskva: In-t jekonomiki perehodnogo perioda.

7. Hromov Ju. (1995). Problemy prodovol'stvennoj bezopasnosti Rossii:mezhdunarodnye i vnutrennie aspekty. Moskva: RISI.

8. Gumerov R. (1997). Kak obespechit' prodovol'stvennuju bezopasnost' strany? Ros. jekon. Zhurnal, 9, 57-69.

9. Ogluzdin N.S. (2006). Prodovol'stvennaja bezopasnost' Rossii. URL: http://geopolitika.narod.ru/ (Retrieved 18.03.2021).

10. Alshanov A. A. (2006.). Kazahstan na mirovom agrarnom rynke: dostizhenija i perspektivy. Kazahstanskaja pravda, 233, p. 4.

11. Bekenov S.S. (2003). Kriterii i ocenki prodovol'stvennoj bezopasnosti. Vestnik KRSU, 2 URL: http://www.krsu.edu.kg/vestnik/2003/v2/a03. html (Retrieved 22.02.2021). 
12. Satybaldin A.A, Temirova, G.K. , T.A. Zhunisbekova. (2020). Prodovol'stvennaja bezopasnost' Kazahstana: sostojanie i vozmozhnosti. Jekonomika: strategija i praktika, 2, 4-15.

13. Kajgorodcev

A.A.

(2006). Jekonomicheskaja i prodovol'stvennaja bezopasnost' Kazahstana. Voprosy teorii, metodologii, praktiki. Ust'Kamenogorsk: Media-Al'jans.

14. Muhtarova K.S., Kenzhebaeva A.R., Tumbetova A.S. (2003). Jekonomicheskaja bezopasnost' v uslovijah globalizacii. Almaty: Jurist.

15. Spanov M. (1999). Jekonomicheskaja bezopansost': opyt sistemnogo analiza. Almaty: Kazakstan damu instituty.

16. Poslanie Prezidenta RK «Kazahstan v novoj real'nosti: vremja dejstvij». 1/09/2020 URL: https:// primeminister.kz/ru/address/01092020 (Retrieved 24.02.2021)

17. Policy Brief: The Impact of COVID-19 on Food Security and Nutrition JUNE 2020 URL: https:// www.un.org/sites/un2.un.org/files/sg_policy_brief_on_ covid_impact_on_food_security.pdf (Retrieved from 15.02.2021)
18. Global Food Security Index 2020. The Economist Intelligence Unit Limited (2021). URL: https://foodsecurityindex.eiu.com/Home/About (Retrieved 10.02.2021).

19. Kekchebaev E., Zhakupova G. (2020). Marketingovye issledovanija sel'skogo hozjajstva Kazahstana: analiz investicionnoj privlekatel'nosti rynka. URL: http://marketingcenter.kz/20/rynokselskoe-khoziaistvo-kazakhstan.html (Retrieved from 12.03.2021).

20. Kazahstan perehodit $\mathrm{k}$ novomu jetapu obespechenija prodovol'stvennoj bezopasnosti - A. Mamin. Oficial'nyj informacionnyj resurs Prem'erMinistra Respubliki Kazahstan[Electronic resource]. - Mode of access: https://primeminister.kz/ru/news/ kazahstan-perehodit-k-novomu-etapu-obespecheniyaprodovolstvennoy-bezopasnosti-a-mamin-2835810 (Retrieved 25.03.2021).

\section{Information about the authors}

Yeszhanova Zh. Zh. - corresponding author, Candidate of Economic Sciences, Associate Professor of the Department of Finance and Accounting, University of International Business, e-mail: eszhan78@mail.ru, https:// orcid.org/0000-0002-9366-8370

Yermekbayeva D.D. - Head of the Department of Finance and Accounting, University of International Business, PhD, e-mail: ermekbaevad@mail.ru, https://orcid.org/0000-0001-8910-6239

Myrzayeva U.A. - Associate Professor of the Department of Finance and Accounting, University of International Business, Master of Economics, e-mail: mirsaeba@mail.ru, https://orcid.org/0000-0002-2146-4619

\section{Авторлар туралы ақпарат}

Есжанова Ж.Ж. - хат-хабаршы авторы, экономика ғылымдарының кандидаты, Халықаралық бизнес университетінің Қаржы және есеп кафедрасының доценті, e-mail: eszhan78@mail.ru, https://orcid.org/00000002-9366- 8370

Ермекбаева Д.Д. - Халықаралық Бизнес Университетінің Қаржы және есеп кафедрасының меңгерушісі, PhD докторы, e-mail: ermekbaevad@mail.ru, https://orcid.org/0000-0001-8910-6239

Мырзаева У.А. - Халықаралық бизнес университетінің Қаржы және есеп кафедрасының доценті, экономика магистрі, e-mail: mirsaeba@mail.ru, https://orcid.org/0000-0002-2146-4619

Дата поступления: 04.05.2021. Прошла рецензирование: 14.05.2021. Принято решение о публикации: 04.06.2021.

Received: 4.05.2021.

Reviewed: 14.05.2021. Accepted: 04.06.2021.

Қарастыруға қабылданды: 04.05.2021.

Рецензиялауды өтті: 14.05.2021.

Жариялауга қабылданды: 04.06.2021. 